\title{
Saharan Dust Modeling Over the Mediterranean Basin and Central Europe: Does the Resolution Matter?
}

\author{
Laura Palacios-Peña ${ }^{1}$, Raquel Lorente-Plazas ${ }^{2}$, Juan Pedro Montávez ${ }^{1}$ and \\ Pedro Jiménez-Guerrero ${ }^{1,2 *}$
}

${ }^{1}$ Physics of the Earth, Department of Physics, Regional Campus of International Excellence "Campus Mare Nostrum", Campus de Espinardo, University of Murcia, Murcia, Spain, ${ }^{2}$ Biomedical Research Institute of Murcia (IMIB-Arrixaca), Murcia, Spain

\section{OPEN ACCESS}

Edited by:

Raquel Nieto,

University of Vigo, Spain

Reviewed by:

Jose M. Baldasano

Universitat Politecnica de Catalunya

Spain

Begońa Artińano,

Centro de Investigaciones Energéticas, Medioambientales y

Tecnológicas, Spain

*Correspondence:

Pedro Jiménez-Guerrero pedro.jimenezguerrero@um.es

Specialty section:

This article was submitted to

Atmospheric Science,

a section of the journal

Frontiers in Earth Science

Received: 28 August 2019 Accepted: 22 October 2019 Published: 08 November 2019

Citation:

Palacios-Peña L, Lorente-Plazas $R$, Montávez JP and Jiménez-Guerrero $P$ (2019) Saharan Dust Modeling Over the Mediterranean Basin and Central Europe: Does the Resolution Matter?

Front. Earth Sci. 7:290.

doi: 10.3389/feart.2019.00290
The Mediterranean Basin is frequently affected by desert dust outbreaks coming from the north of Africa. The presence of this type of particulate matter (PM) joint to others (in particular, anthropogenic pollution from the intense human activities) makes the air quality over this region a worrying issue. In this sense, an accurate characterization of the dust transport is essential. This study tries to shed some light on the sensitivity of dust modeling to the spatial resolution by using the online integrated meteorological-chemical model (WRF-Chem). Three simulations only differing on spatial resolution (D1 at $1.32^{\circ}$, $\mathrm{D} 2$ at $0.44^{\circ}$ and D3 at $0.11^{\circ}$ ), during a representative omega-blocking situation over Europe causing Saharan dust transport over the Mediterranean and central Europe were evaluated against MODIS and AERONET. This evaluation revealed an improvement in the model AOD representation when resolution becomes finer, specially over the Saharan desert dust affected area. These discrepancies between resolutions could be attributed to changes both in thermodynamics and dynamics, since AOD is sensitive to aerosol mass, size distribution and water uptake. Relative humidity $(\mathrm{RH})$ and PM-ratio $\left(\mathrm{PM}_{2.5} / \mathrm{PM}_{10}\right)$ present non-local differences due to the increase of the resolution as a consequence of changes in the long-range transport spatial pattern. Henceforth, the comparison of wind speed and direction, geopotencial height and sea level pressure (SLP) against ERA5 data shows a better representation of the dynamical patterns when decreasing spatial resolution.

Keywords: Saharan, dust, modeling, resolution, WRF-Chem, aerosols, AOD

\section{INTRODUCTION}

The Mediterranean Basin is home to around 480 million people along its coastal regions and its hydrological basins across three continents: Africa, Asia and Europe (UNEP/MAP-Plan Bleu, 2009). This region is an unique area due to its morphological and geographical characteristics which result in complex atmospheric processes (Jiménez et al., 2006; Gkikas et al., 2012), some of which have a high impact on human activities and safety (Michaelides et al., 2018). For all that, the Mediterranean area may be one of the most sensitive world regions and has been identified as one of the main climate change hotspots (Giorgi, 2006; Diffenbaugh and Giorgi, 2012; Ruti et al., 2016).

One of the atmospheric processes widely affecting the Mediterranean Basin is air quality (Michaelides et al., 2018). Atmospheric particulate matter (PM) receives much public and scientific 
interest due to its significant environmental health risks (EEA, 2011; Díaz et al., 2017; Querol et al., 2019) and climatic effects. Specifically, the Mediterranean Basin is a perfect testbed for the study of atmospheric aerosols, since it presents an intense formation, accumulation and re-circulation of aerosols (Millán et al., 1997; Pérez et al., 2004; Querol et al., 2009; Ealo et al., 2016) from different sources as desert dust from the Sahara; sea salt; biomass burning from fires (especially in summer); particles with anthropogenic origin; and, eventually, volcanic ash. All of these facts joint to its geographical position and complex terrain make the role of aerosols even more crucial over the Mediterranean area (Papadimas et al., 2012) with a more intensive impact of aerosol effects than over central Europe (Andreae et al., 2002), especially in summer when the aerosol forcing is greater (Charlson et al., 1992).

Saharan desert dust is one of the major component of these atmospheric aerosols over the Mediterranean (Michaelides et al., 2018), being considered as the largest $\mathrm{PM}_{10}$ source at urban and rural sites in the Mediterranean Basin (Kaskaoutis et al., 2012; Pey et al., 2013). Moreover, more than half of the total natural dust emissions are coming from the Sahara emission sources (Goudie, 2009; Huneeus et al., 2011; Shao et al., 2011; Ginoux et al., 2012) and around 10\% of these Saharan dust aerosols are carried to Europe by crossing the Mediterranean Basin during strong outbreaks (Moulin et al., 1998; Barnaba and Gobbi, 2004; Israelevich et al., 2012; Pey et al., 2013). As pointed out by Rodríguez et al. (2001) and Pandolfi et al. (2011), this north African dust produces a regional effect in the Mediterranean region.

In addition, aerosols in general (and desert dust in particular) are important forcing agents which modify the Earth's energy budget through aerosol-radiation (ARI) and aerosol-clouds (ACI) interactions (Randall et al., 2007; Boucher et al., 2013). ARI are highly dependent on aerosol optical properties because they occur due to aerosol scattering and absorption of radiation. On the other hand, ACI modify clouds properties affecting both radiation and precipitation. Due to these effects, together with clouds, atmospheric aerosols are one of the forcing agents with the largest uncertainty in the climate system (Randall et al., 2007; Boucher et al., 2013).

For all these reasons, an accurate characterization of the transport of desert dust from northern Africa and its effects over the Mediterranean Basin is crucial. A wide number of works have characterized its transport pattern (Moulin et al., 1998; Escudero et al., 2005; Cachorro et al., 2006; Meloni et al., 2007; Barkan and Alpert, 2008; Salvador et al., 2013), the characteristic of the dust outbreaks (Guerzoni et al., 1997; Gkikas et al., 2016) and the properties of these particles (Guerzoni et al., 1997; Nisantzi et al., 2015). All these studies, among many others, are based mainly on observations.

However, modeling tools and applications are receiving increasing attention in the study of desert dust due to their potential (Pérez et al., 2011; Huneeus et al., 2016). Some works combine modeling and observational approaches, as Schulz et al. (2009), where an intercomparison in the framework of the global aerosol model (AeroCom) initiative was performed; or Basart et al. (2016) where nine European regional dust models were intercompared. But these works evidence the challenge in dust modeling because of the high uncertainties associated to the accurate description of several processes (Rizza et al., 2017), which are mainly related to emissions, re-suspension processes, aerosol chemistry, and meteorological conditions strongly influencing spatio-temporal dust transport (e.g., Knippertz and Todd, 2012). Additionally, the location of the Mediterranean in a transitional band between the subtropical and the mid-latitude zones renders the modeling of this region a very challenging task (Planton et al., 2012).

Several works have studied the sensitivity of dust models to several parameterizations such as emission schemes (Flaounas et al., 2017), dust properties (Colarco et al., 2014) or the inclusion of ARI+ACI processes (Solmon et al., 2008; Baró et al., 2017; Palacios-Peña et al., 2017, 2018; Gkikas et al., 2018; Klingmüller et al., 2019). Nevertheless, the literature focused on the impact of the spatial resolution on the modeled dust intrusion is limited. Meanwhile, works assessing the added value of increasing the spatial resolution to several meteorological variables, that strongly impact on dust transport and emissions, have been boosted in the last decade.

Although increasing the spatial resolution does not need to be associated per se with increased model skill, most studies focusing on thermal and hydrological regimes have found increased skills with increased resolution (Whetton et al., 2001; Kusunoki et al., 2006; Hohenegger et al., 2008). In particular, for precipitation using the Weather Research and Forecasting (WRF) Model, Rasmussen et al. (2011) investigated different model resolutions, concluding that a horizontal resolution of $6 \mathrm{~km}$ or less allows to provide an accurate representation the spatial variability in winter in Colorado. Similar results were obtained by Prein et al. (2013). Pieri et al. (2015) demonstrated that the finer resolution is able to reduce the precipitation overestimation in WRF caused by an overrepresentation of convective events. However, Chan et al. (2014) pointed out that the added value of high resolution in precipitation fields in regional climate simulations remains unclear. These authors revealed that only a clear added value is found for accumulation periods shorter than the daily time scale over the southern United Kingdom.

In addition, dust modeling is highly dependent on wind estimations, therefore having an accurate representation of winds becomes essential. In this sense, Santos-Alamillos et al. (2013) found a much higher trend in the error of wind estimation using the WRF model with coarser spatial resolution. Hence, a finer resolution is expected to lead to more accurate dust modeling simulations. Pryor et al. (2012) showed that the influence of model resolution is more relevant in the wind extremes than in the central tendency. Also, larger changes of winds were observed at the lowest model level as model resolution increases. Moreover, Pryor et al. (2012) also demonstrated that increasing the spatial resolution increases the variability of the synoptic- and meso-scales, which not necessarily implies a better agreement with the observations. On the other hand, several studies showed that decreasing grid spacing produces more realistic mesoscale structures (Mass et al., 2002; Rauscher et al., 2010) and convection situations (Braun and Tao, 2000) when increasing resolution. 


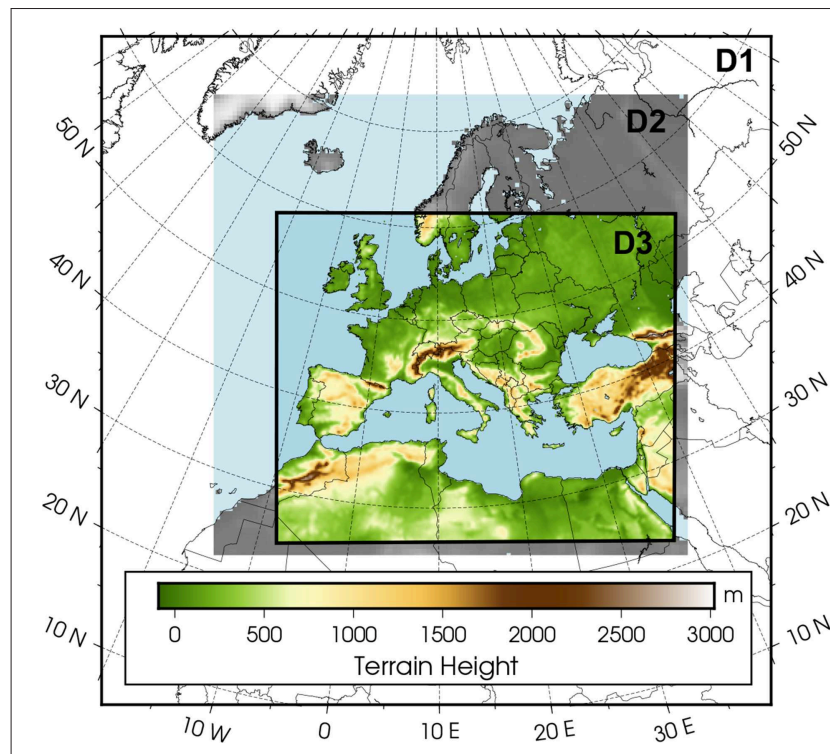

FIGURE 1 | Orography and boundaries of the simulated domains at $1.32^{\circ}$, $0.44^{\circ}$, and $0.11^{\circ}$ horizontal spatial resolutions.

Regarding dust emissions, Liu and Westphal (2001) evaluate the dependence of dust production on model grid-space resolution using a dust emission model embedded in a mesoscale meteorological model and found a positive bias in wind speed that decreases as resolution increases, as estimated dust fluxes.

Henceforth, this work tries to shed some light on the sensitivity of dust modeling to the horizontal spatial resolution over the Mediterranean Basin and Central Europe using the online integrated meteorological-chemical model WRF-Chem. This model allows an online representation of ARI and ACI, thus meteorological variables are affected by aerosol effects. This will also affect the dust emissions and chemical transport.

\section{DATA AND METHODS}

The strategy for assessing the role of the spatial resolution for dust modeling consists on on-line simulations of aerosols and meteorology (ARI and ACI). We focused on a typical desert dust transport episode (described in section 2.1) affecting the Mediterranean Basin and Central Europe, where different types of aerosol (particularly dust) are together producing a high impact on air quality and aerosol load (Millán et al., 1997; Pérez et al., 2004; Querol et al., 2009; Papadimas et al., 2012).

\subsection{Case Study: 1st-9th July 2015}

As mentioned above, the impact of the spatial resolution on dust modeling is evaluated here for a typical episode of dust transport from the Sahara over the Mediterranean region and Central Europe. The episode covering 1st to 9th of July, 2015 has been selected as representative of these situations.

Figure 2 displays the synoptic situation averaging daily fields during the complete period of the geopotential height (colors), wind direction (white arrows) and the sea-level pressure
(SLP, contours) using ERA5 data. This episode presents a typical omega-blocking situation with low pressure over western England. This situation induces the penetration of warm air and dust from northwestern Africa toward northern Europe crossing the western Mediterranean Sea (Nabat et al., 2015). On the 3rd of July, 2015 a tongue of warm air reaches the Scandinavian Peninsula covering most of the European continent. After that, the omega-blocking situation weakens and warm air moves back toward the south concentrated over the western Mediterranean region in a cyclonic circulation. During the end of this episode zonal winds dominate over central Europe carrying atmospheric dust toward the Balkan Peninsula.

This episode represents a dust transport situation over the Iberian Peninsula and the Mediterranean Sea similar to those classified as "North African High Located at Upper Levels" (NAH-A) and "Atlantic Depression" (AD) by Escudero et al. (2005). In this case, Atlantic low is displaced to the north, avoiding wet depositions. As described in Rodríguez et al. (2001) and Escudero et al. (2005), this type of episodes is characterized by strong convective vertical injection of dust over the Sahara, which are transported north toward the Atlantic zone or the Iberian Peninsula and the Mediterranean Sea. NAH-A is the type of outbreak predominant over the Iberian Peninsula, and accounted for $46 \%$ of summer situations in this area (Escudero et al., 2005). The selected episode for this study clearly captures these transport patterns caused by the omega blocking, with dust fluxes penetrating from northwestern Africa to the Iberian Peninsula, the Mediterranean Sea and Central Europe.

\subsection{Model Setup}

Simulations are conducted by WRF-Chem (Grell et al., 2005) version 3.9.1.1. since it is a fully online coupled model and permits the simulations of emissions, transport, mixing and chemical transformation of trace gases and aerosols simultaneously with the meteorology and, thus, includes the treatment of ARI and ACI.

In order to inspect the impacts of the spatial resolution, three simulations have been run. The first simulation encompasses domain D1 (blanked domain in Figure 1) which covers the region $10-72^{\circ} \mathrm{N}$ and $25^{\circ} \mathrm{W}-45^{\circ} \mathrm{E}$ with $1.32^{\circ}$ spatial resolution. In this simulation lateral boundary conditions are provided by the reanalysis data. This region extends further south in order to capture the total desert dust emissions from the Sahara Desert located around $15^{\circ} \mathrm{N}$ (Goudie and Middleton, 2001, 2006; Middleton and Goudie, 2001). For the second simulation the spatial resolution increases to $0.44^{\circ}$ using an one-way nested domain located at $\sim 27^{\circ}-72^{\circ} \mathrm{N}$ and $22^{\circ} \mathrm{W}-45^{\circ} \mathrm{E}$ (gray scale in Figure 1) with complaining EuroCORDEX domain standards (Jacob et al., 2014). In the third simulation, the domain (D3) is focused on the target area and covers the Mediterranean Basin between $27-58^{\circ} \mathrm{N}$ and $10^{\circ} \mathrm{W}-40^{\circ} \mathrm{E}$ (inner domain in Figure 1) with the finest resolution of $\sim 0.11^{\circ}$, as this represent the finest target resolution in EuroCORDEX. All the domains have been run by using one-way nesting with a 1:3 ratio with respect to the larger domain. Thus, the D2 boundaries come from the largest domain (D1) and the finest domain boundaries (D3) come from D2, which ensures an appropriate representation of desert dust 


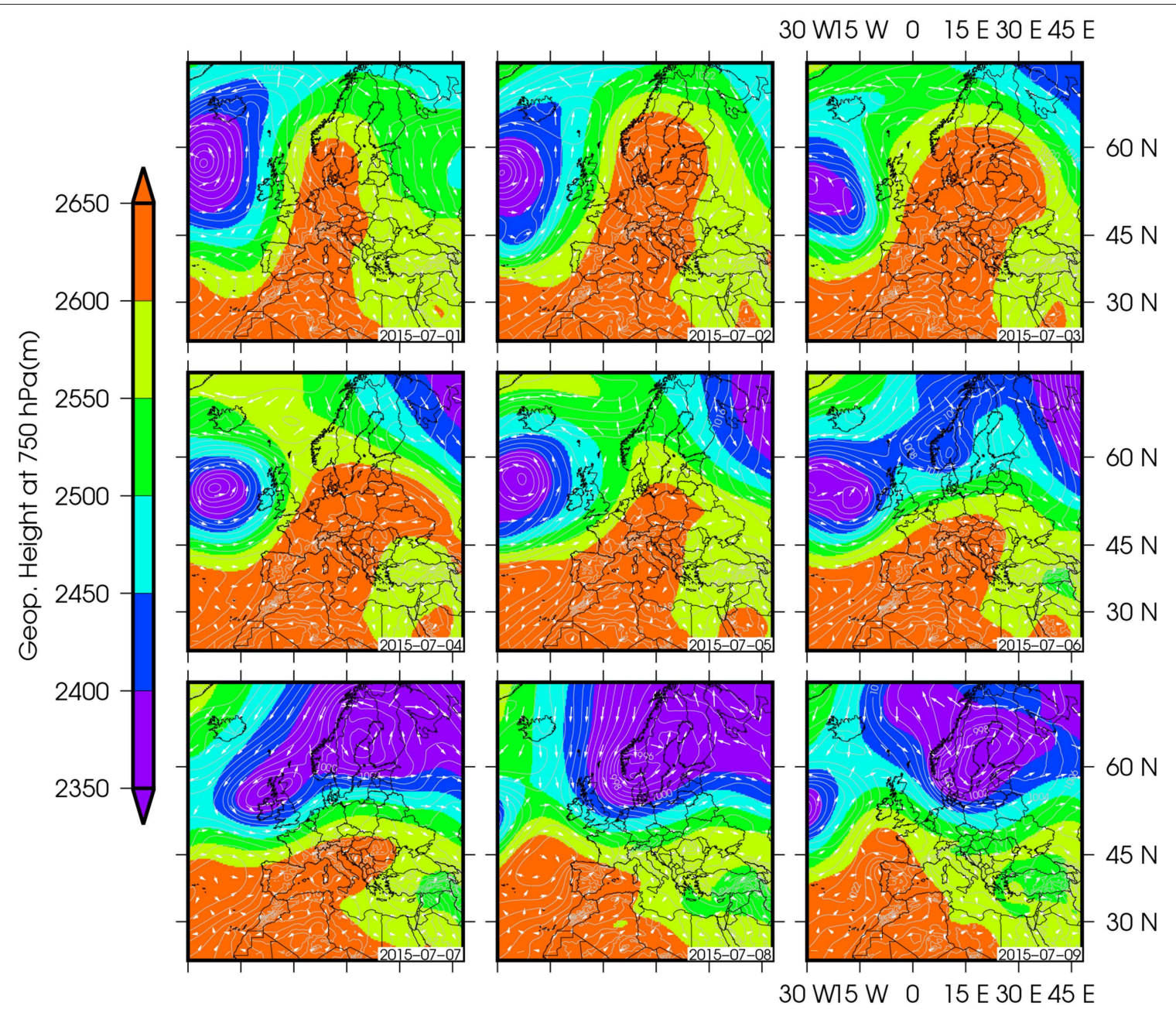

FIGURE 2 | Synoptic situation of Saharan desert dust outbreak between 1st and 9th of July 2015. Colors display geopotencial height in m at 750 hPa; white arrows, wind direction at the same pressure level; and gray lines, the sea level pressure (SLP) in hPa.

emissions and transport through the boundaries. Moreover, a finer resolution simulation has not been carried out, because this would imply convection processes to be solved explicitly (convection is parameterized in D1, D2, and D3), and hence changes observed in finer resolution could not be attributed to the modified resolution, hampering the analysis.

The model physics configuration consisted on: Morrison microphysics (Morrison et al., 2009); the Rapid Radiative Transfer Model (RRTM) short and long wave radiation schemes (Iacono et al., 2008); the Yonsei University (YSU) planetary boundary layer scheme (Hong et al., 2006); the Grell-Freitas ensemble cumulus scheme (Grell and Freitas, 2014) and the Noah soil option (Tewari et al., 2004).

Vertical resolution is 48 uneven layers with the highest resolution at the bottom of the atmosphere and the top at 50 $\mathrm{hPa}$. The higher resolution at the bottom has been chosen with the objective of improving aerosol representation and processes which took place close to the Earth surface. This also improves the representation of the transport, in particular, in the boundary layer. Moreover, as these simulations include ARI and ACI, the RRTM longwave and shortwave schemes are mandatory and these parameterizations only work with the same vertical resolutions for the nested domains.

Meteorological initial and boundary conditions (BC) were provided by the ERA-Interim reanalysis (Dee et al., 2011) developed at the European Centre for Medium-Term Weather Forecast (ECMWF). This reanalysis has a $0.7^{\circ}$ spatial resolution and BCs were updated every $6 \mathrm{~h}$. Chemical BC are idealized gases and aerosol profile as WRF-Chem option.

The chemical configuration consisted on: the RACM-KPP gas-phase scheme (Stockwell et al., 2001; Geiger et al., 2003); the GOCART aerosol scheme (Ginoux et al., 2001; Chin et al., 2002); Fast-J (Fast et al., 2006) for the photolysis; dry deposition is estimated by Wesely (1989) and wet deposition is also calculated with grid-scale wet deposition.

Anthropogenic emissions come from the EDGAR-HTAP project (Janssens-Maenhout et al., 2012, http://edgar.jrc.ec. europa.eu/htap.php) by country and sector with a spatial 
resolution of $0.1^{\circ}$. This project compiled a global emission dataset with annual official or scientific inventories at the national or regional scale for $\mathrm{CH}_{4}, \mathrm{NMVOC}, \mathrm{CO}, \mathrm{SO}_{2}, \mathrm{NO}_{x}, \mathrm{NH}_{3}, \mathrm{PM}_{10}$, $\mathrm{PM}_{2.5}$, black carbon and organic carbon and covering the period 2000-2005. The EDGAR-HTAPv2 emissions were pre-processed by Freitas et al. (2011). Biomass burning emission data have been calculated from global fire emission data supplying by the Integrated Monitoring and Modeling System for wild land fires (IS4FIRES, Sofiev et al., 2009; Soares et al., 2015) with $0.1^{\circ}$ spatial resolution. WRF-Chem emission species have been calculated by chemical speciation following Andreae and Merlet (2001) and Wiedinmyer et al. (2011); and plume rise calculation were online estimated by WRF-Chem.

Biogenic emissions are based on the Model of Emissions of Gases and Aerosols from Nature model (Guenther et al., 2006, MEGAN) which is online coupled with WRF-Chem and makes use of simulated temperature and solar radiation. Finally, dust (Ginoux et al., 2001) and sea salt GOCART (Goddard Global Ozone Chemistry Aerosol Radiation and Transport model, Chin et al., 2002) emissions were online estimated by WRF-Chem.

The dust flux in GOCART is estimated as follows:

$$
F_{p}= \begin{cases}C S s_{p} u_{10 m}^{2}\left(u_{10 m}-u_{t}\right) & \text { if } u_{10 m}>u_{t} \\ 0 & \text { otherwise }\end{cases}
$$

where $C$ is a dimensional factor equal to $1 \mu \mathrm{g} \mathrm{s} \mathrm{m}^{-1} ; S$ is the source function of dust (which establishes the probability to have accumulated sediments depending on the altitude); $u_{10 m}$ is the horizontal wind speed at $10 \mathrm{~m} ; u_{t}$ is the threshold wind velocity (which depends on surface wetness, the particle diameter, the acceleration of gravity and the particle and air density); and $s_{p}$ is the fraction of each size class established in 0.1 for the class $0.1-$ $1 \mu \mathrm{m}$ and $1 / 3$ for the classes $1-1.8 \mu \mathrm{m}, 1.8-3 \mu \mathrm{m}$, and 3-6 $\mu \mathrm{m}$, respectively (Ginoux et al., 2001).

\subsection{Model Evaluation}

The skill of the model to represent the aerosols load in the Mediterranean atmosphere is evaluted by comparing the modeled aerosol optical depth (AOD) against remotesensing data at different wavelengths from MODIS (Moderate Resolution Imaging Spectroradiometer) and AERONET (Aerosol Robotic Network).

First, following Palacios-Peña et al. (2019), satellite AOD at $550 \mathrm{~nm}$ has been taken from an hourly combination of data from the twin MODIS sensors: Terra (MOD04_L2) and Aqua (MYD04_L2). These are the Level 2 of the Atmospheric Aerosol Product of Collection 6 (C6) with a resolution of $\sim 10 \mathrm{~km}$ which were estimated by two different algorithms: Dark Target (DT) and Deep Blue (DB). This satellite product has been widely evaluated (Sayer et al., 2014; Mhawish et al., 2017; Bilal et al., 2018) establishing a high percentage of retrievals within the estimated error (EE) of the DT and DB algorithms, which is $( \pm 0.05+15 \%)$ (Levy et al., 2013).

In addition, for a more robust validation, AOD at 675 $\mathrm{nm}$ has also been evaluated by using available data from
AERONET stations within the target domain. Data has been taken from Level 2.0, which presents an error, under cloud-free conditions, of $< \pm 0.01$ for $\lambda>440 \mathrm{~nm}$ and $< \pm 0.02$ for shorter wavelengths (Holben et al., 1998). Instantaneous shipborne AOD measurements from the Maritime Aerosol Network (MAN) has been also used. In this case, as for MODIS, AOD at $550 \mathrm{~nm}$ is used. As this network is associated with AERONET and uses its standards, AOD uncertainty is $< \pm 0.02$ (Smirnov et al., 2009). Further details on the evaluation of the model using MODIS, MAN and AERONET can be found in Palacios-Peña et al. (2018) and Palacios-Peña et al. (2019).

Finally, atmospheric variables are validated by comparing against ERA5 reanalysis (C3S, 2019). This database covers the Earth on a $30 \mathrm{~km}$ horizontal grid using 137 vertical levels from the surface up to a height of $80 \mathrm{~km}$ and provides hourly estimates of a large number of atmospheric, land and oceanic climate variables, currently from 1979 to within 3 months of real time. The assessed atmospheric variables from ERA5 are geopotential height (Z), wind speed (WS), relative humidity $(\mathrm{RH})$ and the sea-level pressure (SLP).

\section{RESULTS AND DISCUSSION}

\subsection{Are Simulations Skillful for Representing Desert Dust Outbreaks?}

In this section, the aerosol optical depth is evaluated. AOD at $550 \mathrm{~nm}$ is compared against data from the satellite instrument MODIS and from the instantaneous measurement of the MAN network. In addition, AOD at $675 \mathrm{~nm}$ is compared against data from AERONET stations.

Figure 3A displays AOD at $550 \mathrm{~nm}$ from MODIS (shadow), from the MAN network (magenta diamonds) and AOD at 675 $\mathrm{nm}$ from AERONET (circles). MAN data are instantaneous measurements from a boat between 5 th and 9th July 2015. Values estimated by satellite (temporal and spatial mean of 0.22 ) are lower than those measured by AERONET stations (mean of 0.15 ) but this might be ascribed to the different wavelength used for MODIS $(550 \mathrm{~nm}$ ) and AERONET $(675 \mathrm{~nm})$. The AOD is higher than 0.4 over the western Mediterranean Basin (east of the Iberian Peninsula and Mediterranean coast of Italy) and central Europe (Germany). These high AOD values are caused by a vast desert dust outbreak which took part during the target period. Besides, this type of desert dust outbreak is associated with an anticyclonic situation over the Iberian Peninsula producing a intense vertical injection over the Saharan desert, transporting a high concentration of particles aloft in an air mass nothern Africa, affecting the Mediterranean Sea (Prospero, 1996; Alfaro et al., 1998; Rodríguez et al., 2001; Escudero et al., 2005).

Moreover, also high values are found over northern Germany, the Po valley and eastern Ukraine, which could be attributed to forest fires over these areas. It is noticeable that some forest fires also took place in the eastern Iberian Peninsula during this period. On the other hand, over the eastern Mediterranean Basin, observations point to lower values but over 0.1 , which may be due to the dust transport but with a lower load than over the western 

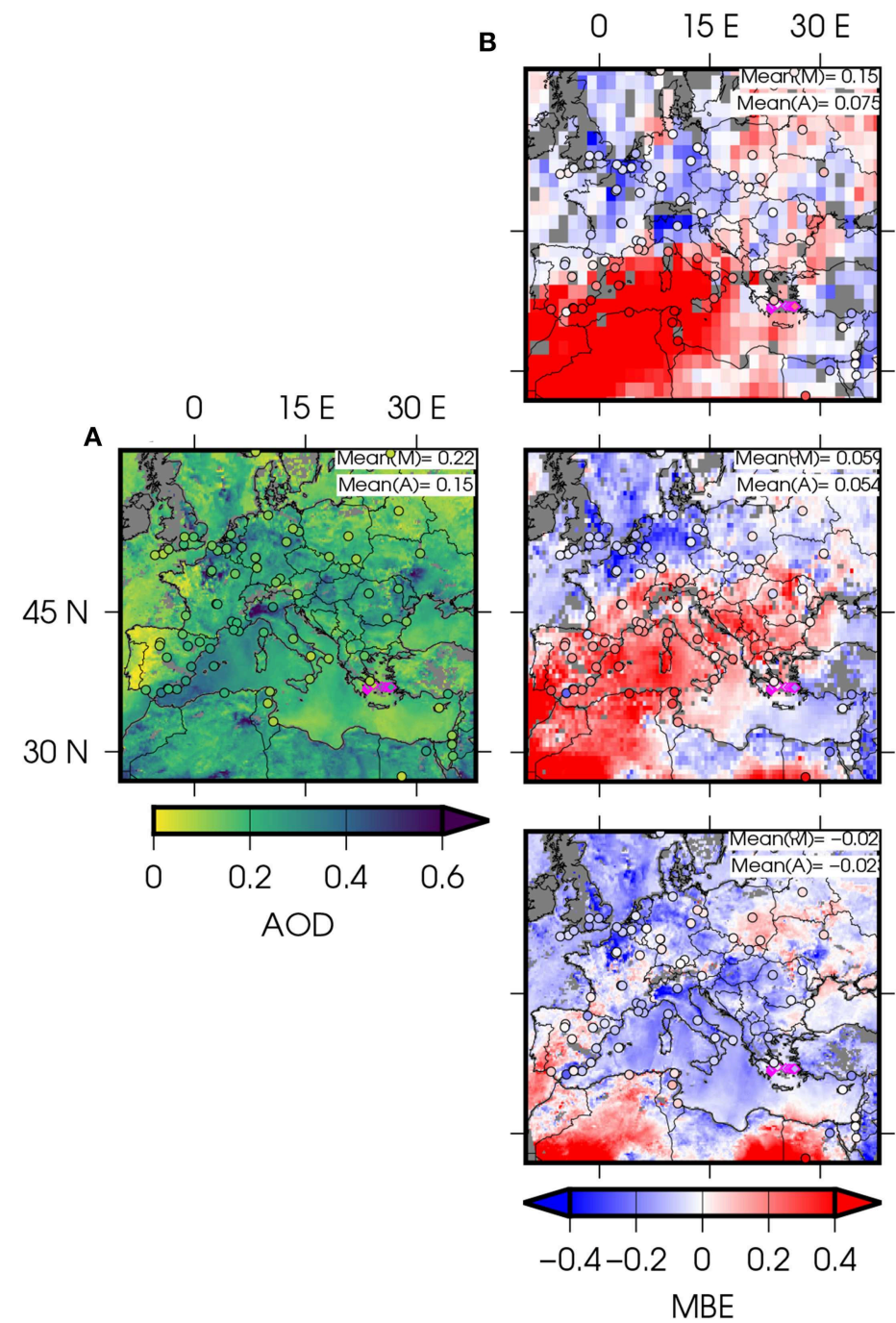
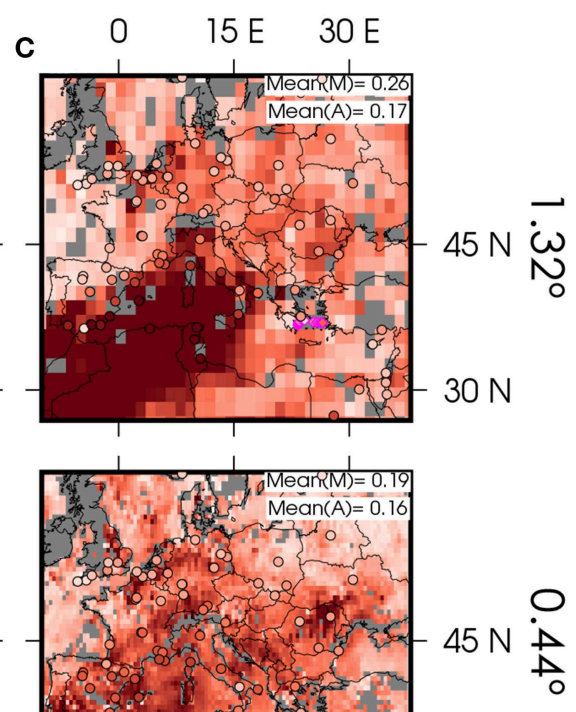

$30 \mathrm{~N}$

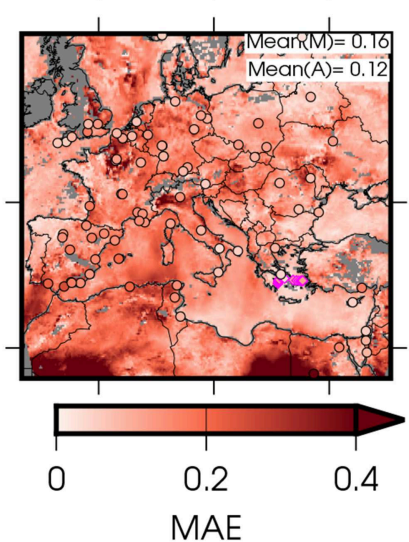

FIGURE 3 | Aerosol optical properties evaluation. (A) AOD (550 nm) from satellite (shadow), MAN network (diamonds) and AOD (675 nm) from AERONET (points). In second and third columns show the same as first but for: (B) MBE and (C) MAE. Top, the coarsest resolution $\left(1.32^{\circ}\right)$, center $\left(0.44^{\circ}\right)$, and bottom $\left(0.11^{\circ}\right)$, the finest resolution.

part of the target domain. Negligible values are measured over the western parts of the Iberian Peninsula and France.

The optical properties are evaluated by computing the Mean Bias Error (MBE) and the Mean Absolute Error (MAE) of the simulations with different resolution when compared against MODIS, AERONET and MAN data (Figure 3 second and third column). Overall, AOD errors decrease as spatial resolution increases. MAE values evidence this behavior. The temporal and spatial mean of MAE computed with MODIS (AERONET) is $0.26(0.19)$ for the coarsest resolution $\left(1.32^{\circ}\right)$ simulation, 0.19 (0.20) for medium resolution $\left(0.44^{\circ}\right)$ and $0.16(0.12)$ for the finest horizontal resolution $\left(0.11^{\circ}\right)$.

The coarsest-resolution simulation $\left(1.32^{\circ}\right)$ overestimates AOD values over the southwestern part of the target area due to the overestimation in the load of the dust outbreaks, which reaches values higher than 0.4 over most of the Mediterranean
Basin. This is also evident when AOD is evaluated against AERONET stations in the western Mediterranean (Spanish and Italian coasts). However, AOD values over central and eastern Europe are underestimated when comparing with MODIS observations. Over Germany, MBE reaches values around 0.4 but the comparison with AERONET stations shows a weaker underestimation. MBEs are negligible over the eastern Mediterranean and the areas around the Bay of Biscay. Regarding MAE, higher values are above 0.4 over the southwest part of the domain, matching with the overestimation of AOD values caused by desert dust.

In the medium-resolution simulation $\left(0.44^{\circ}\right)$ the overestimation over the southwest of the target domain and the western Mediterranean Basin remains similar to the coarsest-resolution simulation, but with lower error values (MBE between 0.2 and 0.4 ). MBE > 0.4 are found over the Alps, 
southwestern Iberian Peninsula and areas close to the Saharan dust emissions. The overestimation over the Balkan Peninsula is noticeable, with MBE values around 0.2 which did not exist in the coarsest simulation. Nevertheless, underestimation remains similar to the coarsest domain, reaching values around 0.4 over northern Germany. In this case, a weak underestimation, with $\mathrm{MBE}$ close to 0 , is found over the eastern part of the domain, particularly over the eastern Mediterranean Basin. Regarding MAE, values above 0.4 are hardly found over the domain. Only the Alps, the north of Germany, the southwest of the Iberian Peninsula and the areas close to the desert reach these values. Over the central and western Mediterranean Basin MAE is around 0.25 and over the Atlantic and the north of the target area values are close to 0 .

Finally, the finest-resolution simulation $\left(0.11^{\circ}\right)$ displays a really different behavior. While the coarser-resolution domains showed an strong overestimation due to Sahara dust, simulations with this resolution are more in agreement with observation, with negligible errors over large areas. The resolution in this simulation corrects the overestimation in coarser-resolution simulations, with errors close to 0 here (Figure 3C), with MAE of 0.16 (MODIS) and 0.12 (AERONET). Two facts should be highlighted: (1) although weaker, the underestimation of AOD over the north of Germany still remains; and (2) there is a weak underestimation of AOD over the central and western Mediterranean.

This disagreement between the evaluation of the representation of AOD over the Mediterranean could be ascribed to a different transport pattern represented with different resolution. Higher spatial resolution involves further details iwhen solving the local circulation patters and the transport of Saharan dust to the Mediterranean Basin and Central Europe. The causes for the different transport patterns seen in the diverse simulations are explored in the next subsection.

\subsection{Attributing the Factors Causing Differences in AOD Representation}

In the section 3.1 the role of the spatial resolution in representing more accurate AOD values has been demonstrated by lower biases and errors when running simulations at $0.11^{\circ}$ resolution. As pointed out by Rauscher et al. (2010), there are three main factors why model's performance can depend on horizontal resolution: (1) a higher resolution is able to capture fine scale forcings such as topography and land use; (2) physical parameterizations depend on the model grid size as well the time step interval; and (3) more complex is the role that spatial resolution plays to better represent physical interactions between different spatial-temporal scales that may affect to the dynamical structure of weather systems or major circulation features.

Henceforth, in this subsection we will try to attribute (or, at least, to disentangle) the causes behind the modifications of the transport patterns when modifying the horizontal resolution in dust simulations. We will explore those causes altering long-range transport (dynamical causes) but also local/thermodynamic (relative humidity, changes in aerosol mass or size distribution) causes that may affect AOD in the target domain.

\subsubsection{Exploring Dynamical Causes}

Here, we inspect whether the AOD improvement in the finestresolution simulation (D3) comes as a consequence of changes in the transport patterns provoked by dynamical causes. Figure 4 displays daily SLP differences between ERA5 and simulations at different resolutions. At the beginning of the episode, the simulations underestimate the SLP over $60 \mathrm{~N}$ and slightly overestimate the pressures over northern Africa. These biases decrease with the increase of the resolution. On 5th July 2015, the SLP overestimation is extended over southern Europe. At the end of the episode, the coarse resolution simulation underestimates the SLP over western Europe, the medium resolution simulation overestimates the SLP over the northwestern part of the domain and the differences are negligible in the higher resolution simulation. These discrepancies in the SLP are also related with the disagreement in Z750. The simulation is unable to capture the omega blocking and the ridge is weakened in all resolutions.

Since the dust transport is mainly produced aloft, at around $750 \mathrm{hPa}$ (Nabat et al., 2015), we focus on the analysis of wind speed at that pressure level, and this variable is validated using ERA5 reanalysis. In Figure 5 the wind speed bias is depicted in colors and arrows represent the wind direction from ERA5 (black) and modeled for each resolution (green).

The simulations (regardless the spatial resolutions) overestimate the wind speed, resulting in a stronger warm advection than in ERA5 and inducing the dust transport from the Sahara to northern Europe. The differences in the wind direction highlight stronger zonal components in the simulated winds than in the ERA5 reanalysis. These differences in the wind directions account for the differences observed in Figure 6 for Z750. The southwestern winds lead the warm flow to reach higher latitudes in ERA5 than in the simulations where more intense zonal winds makes the warm air mass to concentrate more southern Europe. This could explain the underestimations of AOD over central Europe and the overestimation over the western Mediterranean in simulations D1 and D2.

When the spatial resolution increases to $0.11^{\circ}$, wind speed biases slightly improve but wind direction significantly veers to be more in agreement with ERA5, which is more noticeable at the beginning of the episode. This behavior is also supported by the better representation of Z750 in the finer resolution (Figure 6).

There are two specific areas where the wind speed and direction differences are noticeable. At the beginning of the period, over the Baltic Sea, ERA5 shows winds from the south which are not represented by any of the simulations, no matter the resolution. Afterwards, wind veers to a more zonal direction and the simulations capture this change. However, a negative bias in the wind speed is found over this area at the end of the period. The other remarkable issue is the representation of winds over the central and western part of the Mediterranean. Over this area an overestimation of wind speed is found, which is stronger during the middle of the episode. In addition, the coarsest-resolution domain does not capture the wind direction acurately when compared to ERA5. Wind directions slightly 


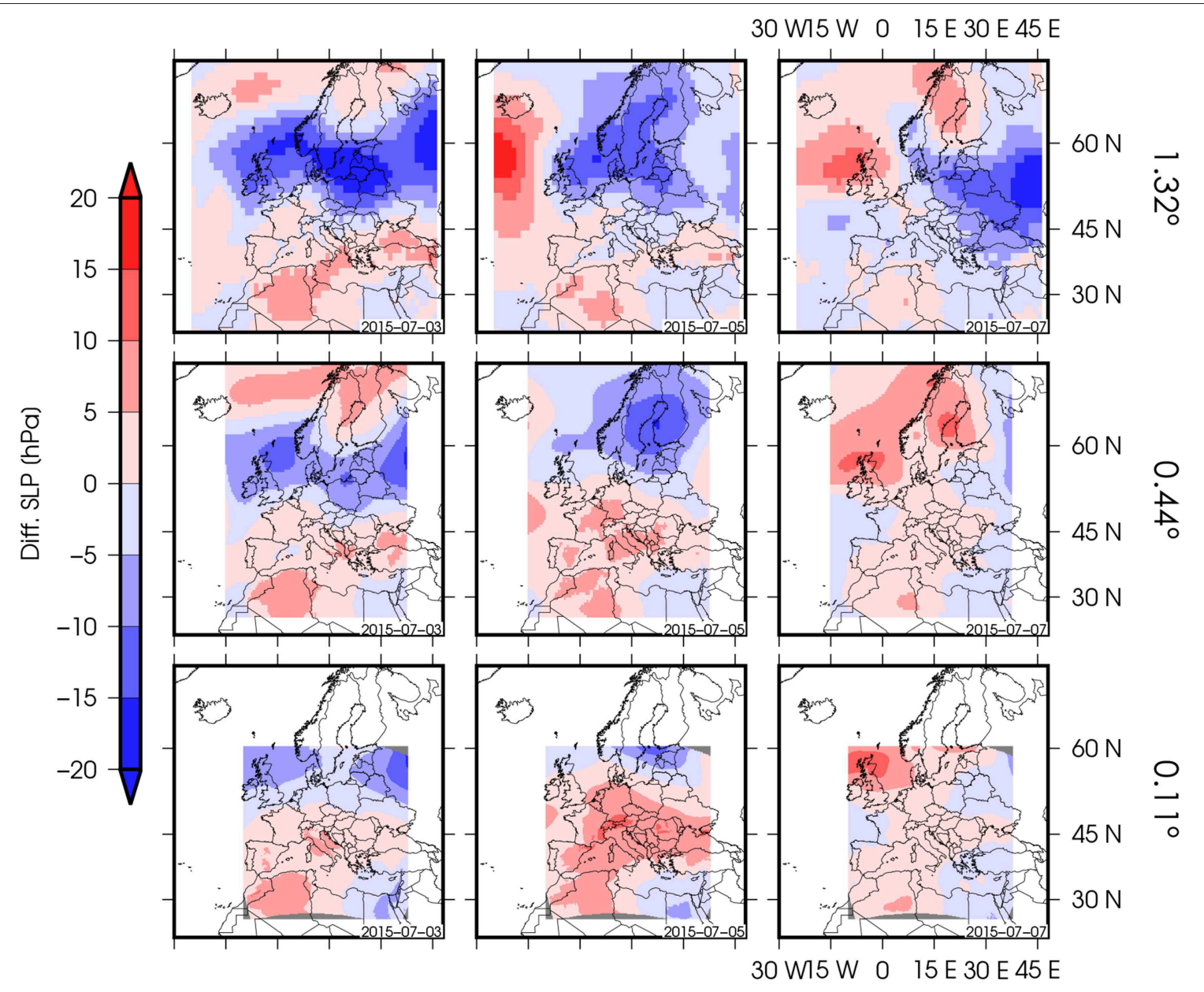

FIGURE 4 | Daily SLP differences between ERA5 and simulations at different resolutions: top row, at $1.32^{\circ}$; second, at $0.44^{\circ}$; and at $0.11^{\circ}$ in third row. Selected days are 3rd, 5th, and 7th of July (left, center, and right, respectively).

improve with finer resolutions, in particular, at the beginning of the period. But later in the period, wind directions are not skilfully represented by any of the simulations. These facts over the Mediterranean could explain the misleading representation of AOD over the central Mediterranean, leading to an important underestimation in the area of the Gulf of Lyon in the finest resolution simulation $\left(0.11^{\circ}\right)$.

The better representationin the finer-resolution simulation of wind speed and direction is in agreement with Santos-Alamillos et al. (2013) work and is expected to generate a more accurate dust transport as also pointed out Liu and Westphal (2001).

\subsubsection{Exploring Local-Thermodynamical Causes}

Once the dynamical causes are established, we explore further the possible local causes behind the changes in AOD representation. Aerosol optical properties, as AOD, are computed by estimating a complex index of refraction function of the chemical components (Fast et al., 2006; Chapman et al., 2009; Barnard et al., 2010), in this case by the Maxwell-Garnett approximation (Bohren and Huffman, 1983) in each given size bin. Last, the composite aerosol optical properties are computed by the
Mie theory and adding over all size bins using wet particles diameters. Thus, locally, AOD representation can be sensitive to: (1) aerosol mass; (2) size distribution and; (3) water uptake, which ultimately depends on the relative humidity $(\mathrm{RH})$ (Palacios-Peña et al., 2017, 2018, 2019).

Figure 7 displays the temporal mean of $\mathrm{RH}$ for the target period at different pressure levels. First row shows ERA5 RH values. Near the surface (1000 hPa) high values (higher than $75 \%$ ) are found over all the seas and the ocean, as well as the British Isles. Over the continent, RH values are lower (around 50\%), particularly over the Iberian Peninsula and the north of Africa (bellow 25\%). Aloft (850 and $750 \mathrm{hPa}$ ) RH values decrease when pressure increases. In detail, $\mathrm{RH}$ is low over the Mediterranean Sea, north of Africa and the Iberian Peninsula at both levels (below 40\%). However, at $750 \mathrm{hPa}$ a lower $\mathrm{RH}$ is found over central Europe and the south of the British Isles (below 50\%). Figure 7, second, third and fourth rows show the differences of each simulations (D1, D2, and D3, respectively) against ERA5. At 1000 and $850 \mathrm{hPa}, \mathrm{RH}$ values over the north of the domain are overestimated and over the south are underestimated. However, these errors are lower for the simulation with the 


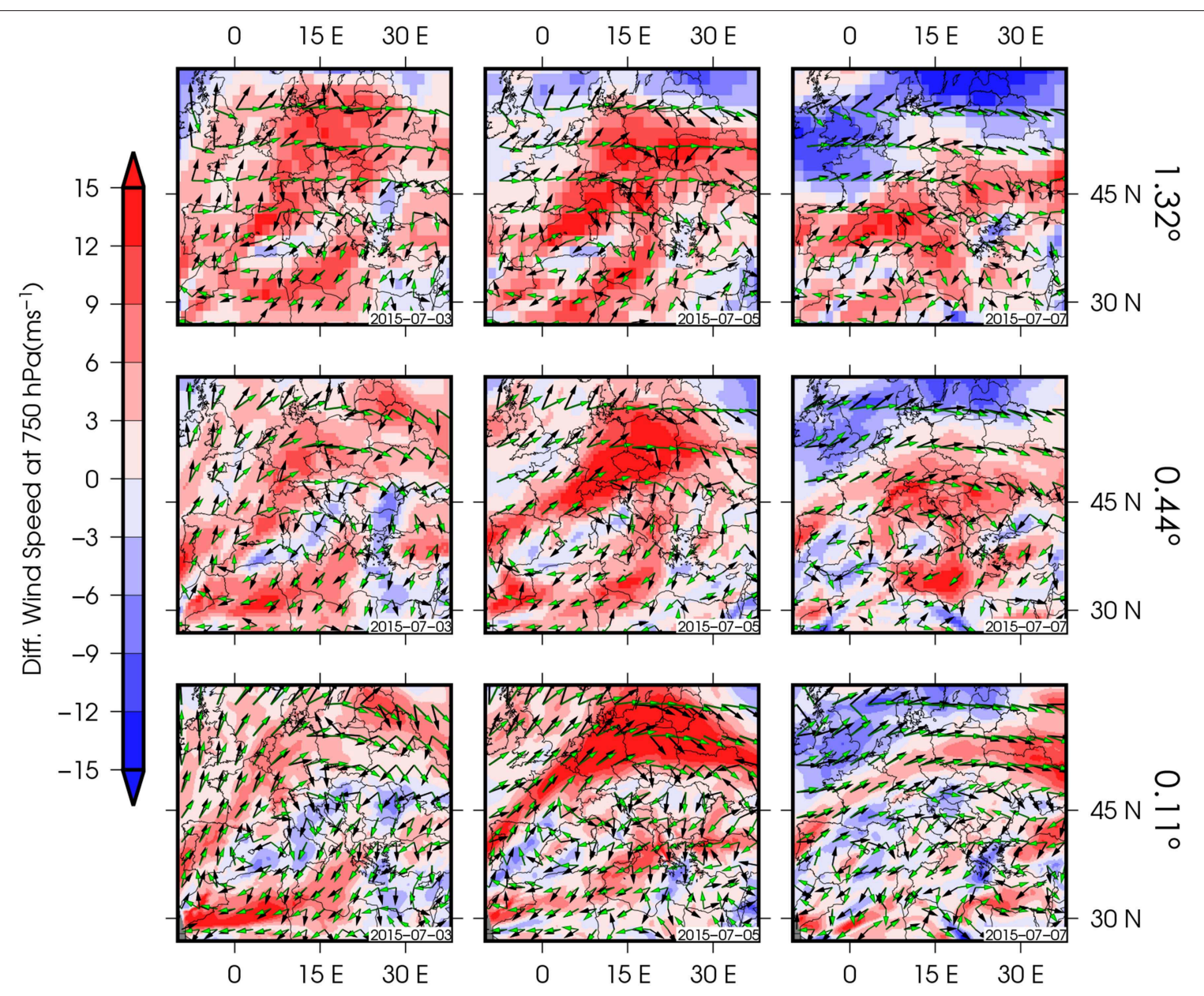

FIGURE 5 | Daily wind speed differences between ERA5 and simulations at different resolutions at $1.32^{\circ}$ (first row), at $0.44^{\circ}$ (second row); and at $0.11^{\circ}$ (third row) during 3rd, 5th, and 7th of July (left, center, and right, respectively). Wind speed bias is depicted in colors and arrows represent the wind direction from ERA5 (black) and modeled (green).

finest resolution (D3). At $750 \mathrm{hPa}, \mathrm{RH}$ values are overestimated over the northwest of the domain D1 but the other finer resolution simulation (D2) weakly underestimates $\mathrm{RH}$ values over that area. Moreover, this underestimation is the weakest for the finest resolution simulation (D3). Over the Balkans and the Anatolian Peninsula, $\mathrm{RH}$ values are underestimated but, again, this underestimation is weaker when the resolution increases.

When compared with Figure 2, the spatial patterns of low RH are similar to the trajectory of warm and dusty air mass. That is, the decrease of RH in central Europe in the D3 simulations is strongly associated to the dry air mass coming from the Saharan desert during the target episode.

This fact above explained is also corroborated by the PM ratio $\left(\mathrm{PM}_{2.5} / \mathrm{PM}_{10}\right)$. Figure 8 represents the $\mathrm{PM}$ ratio between $\mathrm{PM}_{2.5}$ and $\mathrm{PM}_{10}$ for the simulation at $1.32^{\circ}$ and its differences with the finer resolution simulations. Low values of this ratiopoint to a prevalence of $\mathrm{PM}_{10}$ particles over $\mathrm{PM}_{2.5}$ and vice-versa for values close to 1 . For the atmospheric pressure levels analyzed $(1000,850$, and $750 \mathrm{hPa}), \mathrm{PM}$ ratios are low over the north of
Africa and the western part of the Mediterranean Basin. This involves the prevalence of coarse dust particles. Over the eastern Mediterranean Basin and the south of Europe, PM ratio values are lower than 0.5 because these areas were affected by the dust outbreak either with a lower dust concentration or during a shorter period. Over central Europe and the British Isles, values are close to 1 indicating that most of particles are in the fine fraction $\left(\mathrm{PM}_{2.5}\right)$. At $1000 \mathrm{hPa}, \mathrm{PM}$ ratio values over the North Sea are high because of coarse sea salt particles emitted from the ocean. When comparing the coarse-resolution domain (D1) with the $0.44^{\circ}$ resolution simulation (D2), the PM ratio decreases over Central Europe, indicating a higher concentration of $\mathrm{PM}_{10}$ over this area than in the simulation for the coarse resolution. This behavior is similar at all the pressure levels considered. Over the southwestern and central Mediterranean, the PM ratio increases, which involves a lower concentration of coarse particles with respect to the fine fraction. The spatial pattern of differences in the finer-resolution domain $\left(0.11^{\circ}, \mathrm{D} 3\right)$ are similar to the $0.44^{\circ}$ resolution simulation. In this case an important decrease of the PM ratio is found over the same areas and further north. 


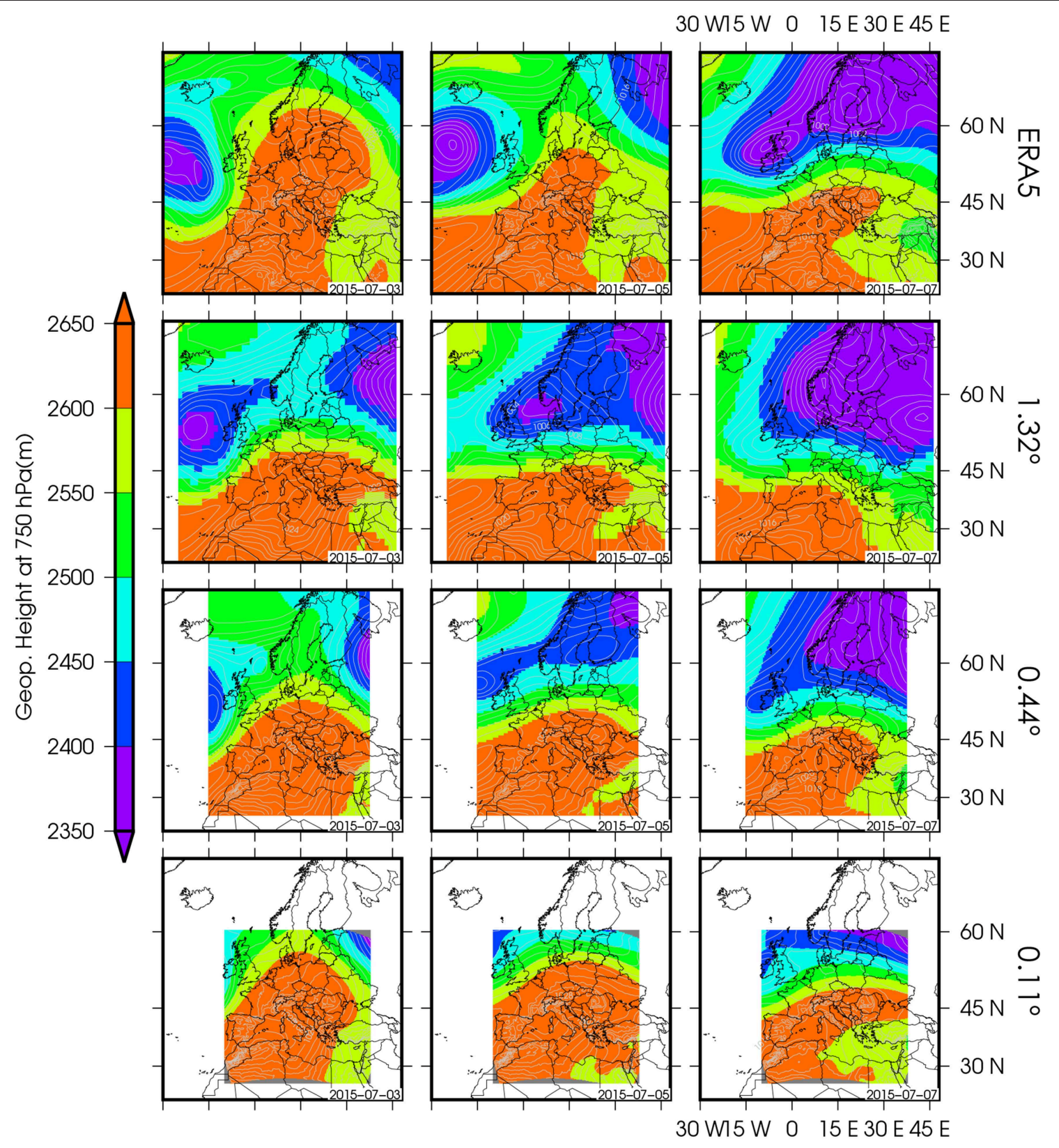

FIGURE 6 | Synoptic situation of Saharan desert dust outbreak. Selected days are 3rd, 5th, 7th July (left, center, and right, respectively). ERA5 at the top row and each resolution from the second $\left(1.32^{\circ}\right)$ to the bottom $\left(0.11^{\circ}\right)$. Colors display geopotential height in $\mathrm{m}$ at $750 \mathrm{hPa}$ and gray lines, the sea level pressure $(\mathrm{SLP})$ in $\mathrm{hPa}$.

Moreover the increase of the ratio over the western/central Mediterranean is now stronger.

Therefore, changes in relative humidity and size of the particles (which may affect AOD) are not produced by local thermodynamic causes, but strongly depend on the long-range transport conditioning the local values of those variables.

\section{CONCLUSION}

In this study the impacts of the spatial resolution on the dust representation by the WRF-Chem online model were evaluated by comparing the simulated AOD against MODIS and AERONET. This observation evaluation revealed an improvement in simulated AOD when resolution becomes finer, specially over the area affected by the Saharan dust. Over this area, the simulation with the finest resolution shows negligible error values over large parts of the target domain.

The discrepancies between resolutions could be, a priori, attributed to both thermodynamics or dynamic changes, since $\mathrm{AOD}$ is sensitive to aerosol mass, size distribution and water uptake. Due to the mass conservation principle in models, aerosol mass coming from the boundaries 


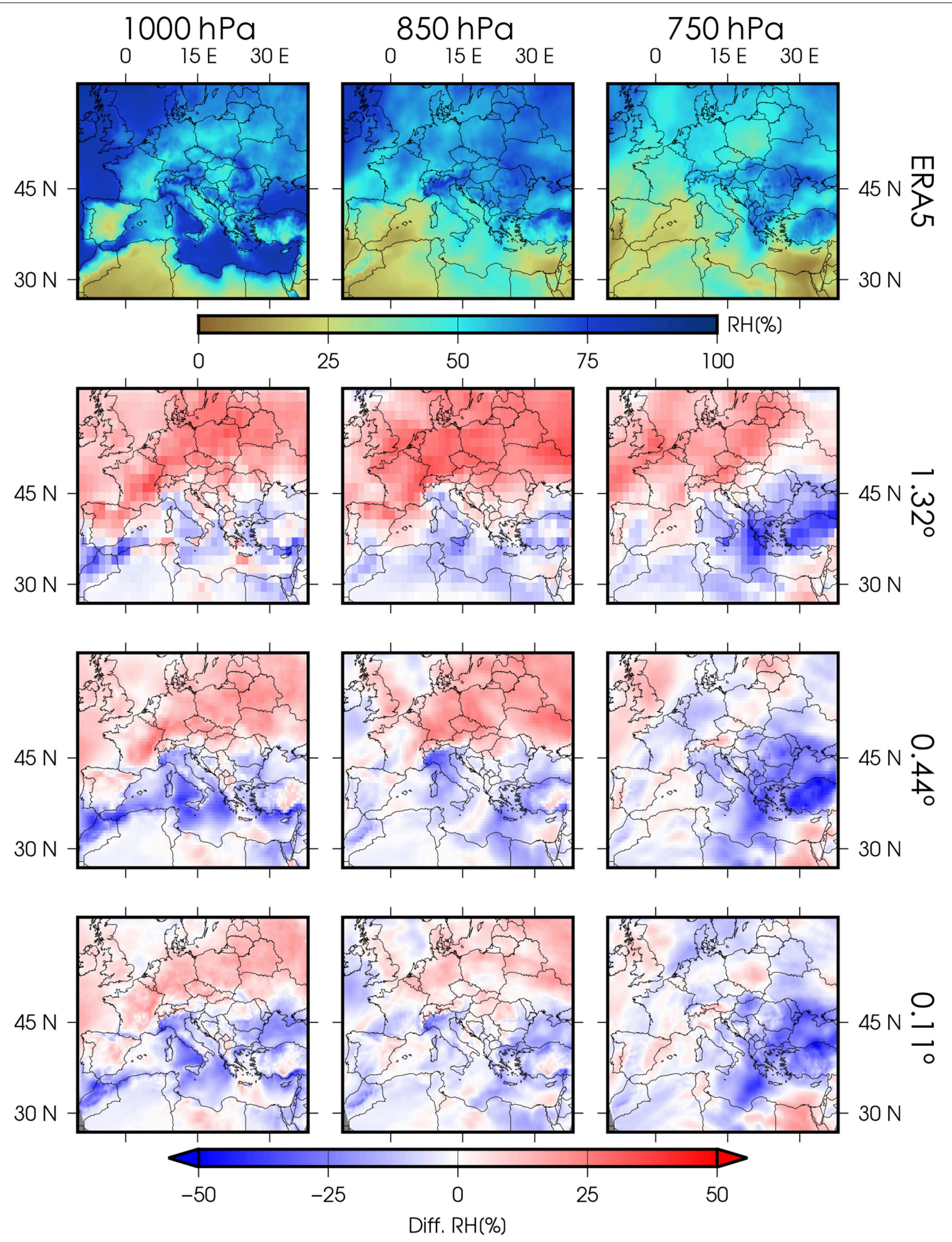

FIGURE 7 | ERA5 relative humidity $(\mathrm{RH})$ at $1000 \mathrm{hPa}$ (left column), $850 \mathrm{hPa}$ (middle column), and $750 \mathrm{hPa}$ (right column) and the differences with each simulation at: second row, $1.32^{\circ}$; third, $0.44^{\circ}$; and fourth, $0.11^{\circ}$.

conditions must be preserved, so, aerosol mass cannot vary between domains. Thus, changes in $\mathrm{RH}$, on which aerosol water uptake depends, and aerosol size distribution between different resolutions were evaluated. These variables present divergence between simulations but these differences do not represent a local impact due to the increase of the resolution 

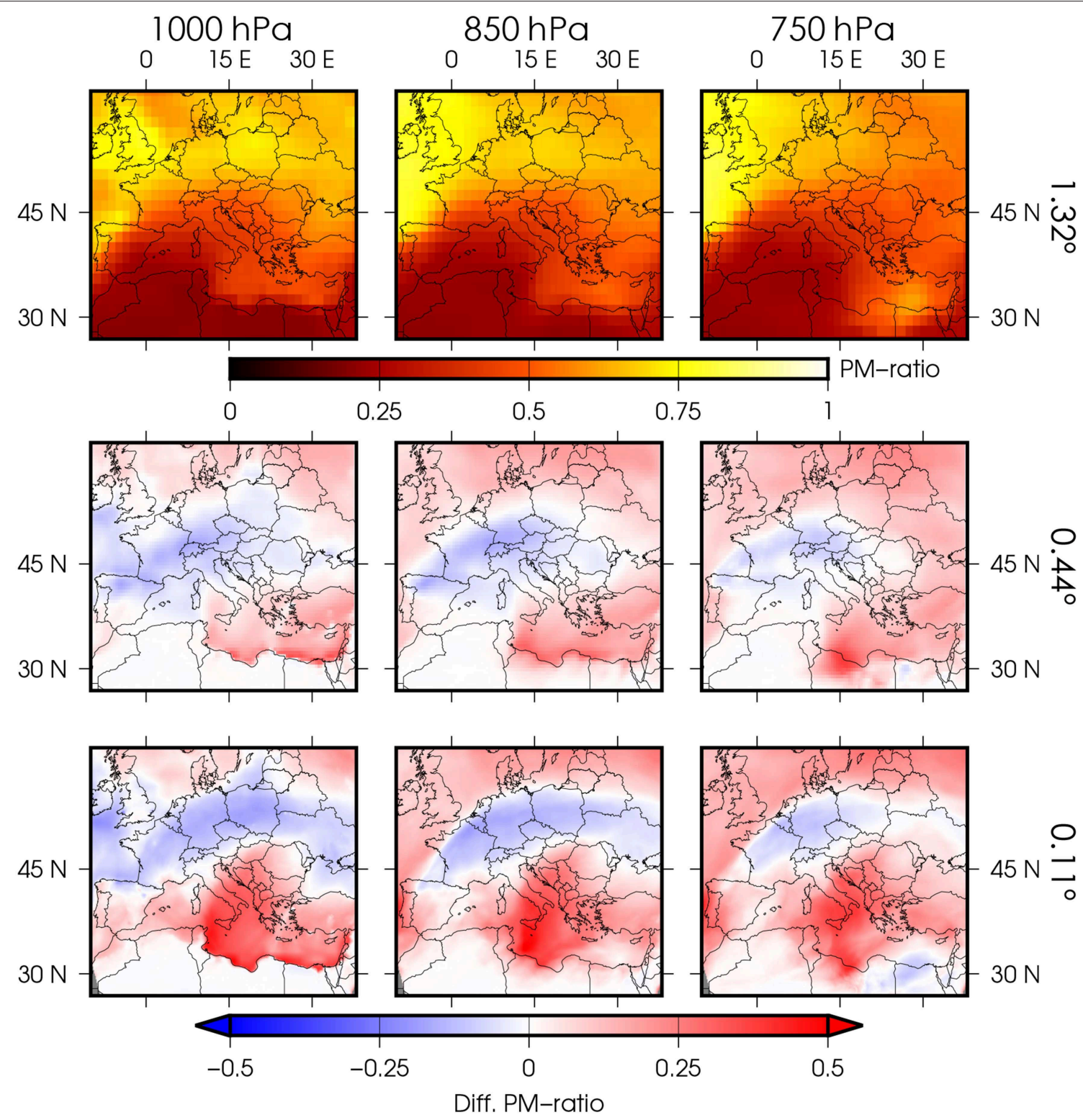

FIGURE 8 | PM-ratio ( $\mathrm{PM}_{2.5} / \mathrm{PM}_{10}$ ) at $1000 \mathrm{hPa}$ (left column), $850 \mathrm{hPa}$ (middle column), and $750 \mathrm{hPa}$ (right column) of simulation at $1.32^{\circ}$ (top). Second and third rows display differences between simulation at $1.32^{\circ}$ and at $0.44^{\circ}$ and at $0.11^{\circ}$, respectively.

because they are consequence of changes in the long-range transport pattern.

Henceforth, the changes in AOD come from the limitations in the representation of the model dynamics. In order to evaluate this issue, wind speed and direction, geopotential height and SLP were analyzed. The finer resolution is able to improve the wind direction injecting the warm air from the Sahara Desert to higher latitudes over Europe at the beginning of the episode. When the spatial resolution increases, SLP underestimation decreases allowing to better capture the omega-blocking situation. Thus, this study evidences the influence of resolution in long-range desert dust transport and its value in the correct simulation of this type of extreme episodes of dust load over the Mediterranean area and Central Europe. Therefore, the changes observed between different domain resolutions can be mainly attributed to a better representation of the dynamical patterns. The improvement of certain circulation features as spatial resolution increases has been demonstrated in previous works covering the Atlantic intertropical convergence zone (e.g., Rauscher et al., 2006), or when representing tropical storms (Oouchi et al., 2006) or monsoon circulations (Stephenson et al., 1998; Gao et al., 2006).

Concluding, increasing the spatial resolution improves the representation of variables associated with dust, such as AOD. RH representation, whom AOD is particularly sensitive, also improve. All of these changes are consequence of an improvement in the representation of dynamical processes in 
regional meteorological/climate models when increasing the horizontal resolution.

The conclusion found in this is study could be relevant for dust forecasting however further studies are needed using larger ensembles of dust simulations. For instance, the use of different parameterizations, the assessment of different study cases or the model response to convective permitting resolutions are key issues to assess for the improvement of dust modeling.

\section{DATA AVAILABILITY STATEMENT}

The datasets are available upon contact with the corresponding author: pedro.jimenezguerrero@um.es.

\section{AUTHOR CONTRIBUTIONS}

LP-P wrote the manuscript, with contributions from PJ-G. JM and RL-P corrected and improved the manuscript. LP-P conducted the numerical simulations and compiled all the

\section{REFERENCES}

Alfaro, S. C., Gaudichet, A., Gomes, L., and Maillé, M. (1998). Mineral aerosol production by wind erosion: aerosol particle sizes and binding energies. Geophys. Res. Lett. 25, 991-994. doi: 10.1029/98GL00502

Andreae, M. O., and Merlet, P. (2001). Emission of trace gases and aerosols from biomass burning. Global Biogeochem. Cycles 15, 955-966. doi: 10.1029/2000GB001382

Andreae, T. W., Andreae, M. O., Ichoku, C., Maenhaut, W., Cafmeyer, J., Karnieli, A., et al. (2002). Light scattering by dust and anthropogenic aerosol at a remote site in the Negev desert, Israel. J. Geophys. Res. 107:4008. doi: 10.1029/2001JD900252

Barkan, J., and Alpert, P. (2008). Synoptic patterns associated with dusty and non-dusty seasons in the Sahara. Theor. Appl. Climatol. 94, 153-162. doi: 10.1007/s00704-007-0354-9

Barnaba, F., and Gobbi, G. P. (2004). Aerosol seasonal variability over the Mediterranean region and relative impact of maritime, continental and Saharan dust particles over the basin from MODIS data in the year 2001. Atmospher. Chem. Phys. 4, 2367-2391. doi: 10.5194/acp-4-2367-2004

Barnard, J. C., Fast, J. D., Paredes-Miranda, G., Arnott, W. P., and Laskin, A. (2010). Technical note: evaluation of the WRF-Chem "Aerosol Chemical to Aerosol Optical Properties" Module using data from the MILAGRO campaign. Atmospher. Chem. Phys. 10, 7325-7340. doi: 10.5194/acp-10-7325-2010

Baró, R., Palacios-Peña, L., Baklanov, A., Balzarini, A., Brunner, D., Forkel, R., et al. (2017). Regional effects of atmospheric aerosols on temperature: an evaluation of an ensemble of online coupled models. Atmospher. Chem. Phys. 17, 9677-9696. doi: 10.5194/acp-17-9677-2017

Basart, S., Dulac, F., Baldasano, J., Nabat, P., Mallet, M., Solmon, F., et al. (2016). "Extensive comparison between a set of european dust regional models and observations in the western mediterranean for the summer 2012 preChArMEx/TRAQA Campaign," in Air Pollution Modeling and its Appliaction XXIV. Springer Proceedings in Complexity, eds D. Steyn and N. Chaumerliac (Cham: Springer).

Bilal, M., Nazeer, M., Qiu, Z., Ding, X., and Wei, J. (2018). Global validation of MODIS C6 and C6.1 Merged Aerosol Products over Diverse Vegetated Surfaces. Remote Sens. 10:475. doi: 10.3390/rs10030475

Bohren, C. F., and Huffman, D. R. (1983). Absorption and Scattering of Light by Small Particles. Weinheim: John Wiley \& Sons.

Boucher, O., Randall, D., Artaxo, P., Bretherton, C., Feingold, G., Forster, P., et al. (2013). "Clouds and aerosols," in Climate Change 2013: The Physical Science Basis. Contribution of Working Group I to the Fifth Assessment Report of the Intergovernmental Panel on Climate Change, eds T. Stocker, D. Qin, G.-K. experiments. LP-P and PJ-G did the analysis, with the support of JM and RL-P.

\section{FUNDING}

The authors acknowledge the funding from projects REPAIRCGL2014-59677-R and ACEX-CGL2017-87921-R, by the Spanish Ministry of the Economy and Competitiveness and the European Regional Development Fund (ERDF/FEDER). LP-P thanks the FPU14/05505 scholarship from the Spanish Ministry of Education, Culture and Sports. RL-P also thanks to the funding received by the University of Murcia through its postdoctoral fellow.

\section{ACKNOWLEDGMENTS}

People involved in WRF-Chem, AERONET, MODIS and ERA5 are acknowledged for providing this study with relevant data.
Plattner, M. Tignor, S. Allen, J. Boschung, A. Nauels, Y. Xia, V. Bex, and P. Midgley (Cambridge; New York, NY: Cambridge University Press), 571-657.

Braun, S. A., and Tao, W.-K. (2000). Sensitivity of high-resolution simulations of hurricane bob (1991) to planetary boundary layer parameterizations. Month. Weather Rev. 128, 3941-3961.

C3S (2019). ERA5: Fifth Generation of ECMWF Atmospheric Reanalyses of the Global Climate. Available online at: https://cds.climate.copernicus.eu/cdsapp\#!/ home (accessed June 15, 2019).

Cachorro, V. E., Vergaz, R., de Frutos, A. M., Vilaplana, J. M., Henriques, D., Laulainen, N., et al. (2006). Study of desert dust events over the southwestern Iberian Peninsula in year 2000: two case studies. Ann. Geophys. 24, 1493-1510. doi: 10.5194/angeo-24-1493-2006

Chan, S. C., Kendon, E. J., Fowler, H. J., Blenkinsop, S., Roberts, N. M., and Ferro, C. A. T. (2014). The value of high-resolution met office regional climate models in the simulation of multihourly precipitation extremes. J. Clim. 27, 6155-6174. doi: 10.1175/JCLI-D-13-00723.1

Chapman, E. G., Gustafson, W. I. Jr., Easter, R. C., Barnard, J. C., Ghan, S. J., Pekour, M. S., et al. (2009). Coupling aerosol-cloud-radiative processes in the WRF-Chem model: investigating the radiative impact of elevated point sources. Atmospher. Chem. Phys. 9, 945-964. doi: 10.5194/acp-9-9452009

Charlson, R. J., Schwartz, S. E., Hales, J. M., Cess, R. D., Coakley, J. A., Hansen, J. E., et al. (1992). Climate forcing by anthropogenic aerosols. Science 255, 423-430. doi: $10.1126 /$ science.255.5043.423

Chin, M., Ginoux, P., Kinne, S., Torres, O., Holben, B. N., Duncan, B. N., et al. (2002). Tropospheric aerosol optical thickness from the GOCART model and comparisons with satellite and Sun photometer measurements. J. Atmospher. Sci. 59, 461-483.

Colarco, P. R., Nowottnick, E. P., Randles, C. A., Yi, B., Yang, P., Kim, K.-M., et al. (2014). Impact of radiatively interactive dust aerosols in the NASA GEOS-5 climate model: sensitivity to dust particle shape and refractive index. J. Geophys. Res. 119, 753-786. doi: 10.1002/2013JD020046

Dee, D. P., Uppala, S. M., Simmons, A. J., Berrisford, P., Poli, P., Kobayashi, S., et al. (2011). The ERA-Interim reanalysis: configuration and performance of the data assimilation system. Q. J. R. Meteorol. Soc. 137, 553-597. doi: 10.1002/qj.828

Díaz, J., Linares, C., Carmona, R., Russo, A., Ortiz, C., Salvador, P., et al. (2017). Saharan dust intrusions in Spain: health impacts and associated synoptic conditions. Environ. Res. 156, 455-467. doi: 10.1016/j.envres.2017. 03.047

Diffenbaugh, N. S., and Giorgi, F. (2012). Climate change hotspots in the CMIP5 global climate model ensemble. Clim. Change 114, 813-822. doi: $10.1007 / \mathrm{s} 10584-012-0570-\mathrm{x}$ 
Ealo, M., Alastuey, A., Ripoll, A., Pérez, N., Minguillón, M. C., Querol, X., et al. (2016). Detection of Saharan dust and biomass burning events using near-realtime intensive aerosol optical properties in the north-western Mediterranean. Atmospher Chem. Phys. 16, 12567-12586. doi: 10.5194/acp-16-12567-2016

EEA (2011). Air Quality in Europe: 2011 Report. Luxembourg: European Environment Agency. Publications Office of the European Union.

Escudero, M., Castillo, S., Querol, X., Avila, A., Alarcón, M., Viana, M. M., et al. (2005). Wet and dry African dust episodes over eastern Spain. J. Geophys. Res. 110:D18S08. doi: 10.1029/2004JD004731

Fast, J. D., Gustafson, W. I., Easter, R. C., Zaveri, R. A., Barnard, J. C., Chapman, E. G., et al. (2006). Evolution of ozone, particulates, and aerosol direct radiative forcing in the vicinity of houston using a fully coupled meteorology-chemistryaerosol model. J. Geophys. Res. 111:D21305. doi: 10.1029/2005JD006721

Flaounas, E., Kotroni, V., Lagouvardos, K., Klose, M., Flamant, C., and Giannaros, T. M. (2017). Sensitivity of the WRF-Chem (V3.6.1) model to different dust emission parametrisation: assessment in the broader Mediterranean region. Geosci. Model Dev. 10, 2925-2945. doi: 10.5194/gmd-10-2925-2017

Freitas, S. R., Longo, K. M., Alonso, M. F., Pirre, M., Marecal, V., Grell, G., et al. (2011). PREP-CHEM-SRC - 1.0: a preprocessor of trace gas and aerosol emission fields for regional and global atmospheric chemistry models. Geosci. Model Dev. 4, 419-433. doi: 10.5194/gmd-4-419-2011

Gao, X., Xu, Y., Zhao, Z., Pal, J. S., and Giorgi, F. (2006). On the role of resolution and topography in the simulation of East Asia precipitation. Theor. Appl. Climatol. 86, 173-185. doi: 10.1007/s00704-005-0214-4

Geiger, H., Barnes, I., Bejan, I., Benter, T., and Spittler, M. (2003). The tropospheric degradation of isoprene: an updated module for the regional atmospheric chemistry mechanism. Atmospher. Environ. 37, 1503-1519. doi: 10.1016/S1352-2310(02)01047-6

Ginoux, P., Chin, M., Tegen, I., Prospero, J. M., Holben, B., Dubovik, O., et al. (2001). Sources and distributions of dust aerosols simulated with the GOCART model. J. Geophys. Res. 106, 20255-20273. doi: 10.1029/2000JD000053

Ginoux, P., Prospero, J. M., Gill, T. E., Hsu, N. C., and Zhao, M. (2012). Globalscale attribution of anthropogenic and natural dust sources and their emission rates based on MODIS Deep Blue aerosol products. J. Geophys. Res. 106, 20255-20273. doi: 10.1029/2012RG000388

Giorgi, F. (2006). Climate change hot-spots. Geophys. Res. Lett. 33:L08707. doi: 10.1029/2006GL025734

Gkikas, A., Basart, S., Hatzianastassiou, N., Marinou, E., Amiridis, V., Kazadzis, S., et al. (2016). Mediterranean intense desert dust outbreaks and their vertical structure based on remote sensing data. Atmospher. Chem. Phys. 16, 8609-8642. doi: 10.5194/acp-16-8609-2016

Gkikas, A., Houssos, E. E., Hatzianastassiou, N., Papadimas, C. D., and Bartzokas, A. (2012). Synoptic conditions favouring the occurrence of aerosol episodes over the broader Mediterranean basin. Q. J. R. Meteorol. Soc. 138, 932-949. doi: $10.1002 /$ qj.978

Gkikas, A., Obiso, V., Pérez García-Pando, C., Jorba, O., Hatzianastassiou, N., Vendrell, L., et al. (2018). Direct radiative effects during intense Mediterranean desert dust outbreaks. Atmospher. Chem. Phys. 18, 8757-8787. doi: $10.5194 /$ acp-18-8757-2018

Goudie, A. S. (2009). Dust storms: recent developments. J. Environ. Manag. 90, 89-94. doi: 10.1016/j.jenvman.2008.07.007

Goudie, A. S., and Middleton, N. J. (2001). Saharan dust storms: nature and consequences. Earth Sci. Rev. 56, 179-204. doi: 10.1016/S0012-8252(01)00067-8

Goudie, A. S., and Middleton, N. J. (2006). Desert Dust in the Global System. Berlin; Heidelberg: Springer-Verlag.

Grell, G. A., and Freitas, S. R. (2014). A scale and aerosol aware stochastic convective parameterization for weather and air quality modeling. Atmospher. Chem. Phys. 14, 5233-5250. doi: 10.5194/acp-14-5233-2014

Grell, G. A., Peckham, S. E., Schmitz, R., McKeen, S. A., Frost, G., Skamarock, W. C., et al. (2005). Fully coupled "online" chemistry within the WRF model. Atmospher. Environ. 39, 6957-6975. doi: 10.1016/j.atmosenv.2005.04.027

Guenther, A., Karl, T., Harley, P., Wiedinmyer, C., Palmer, P. I., and Geron, C. (2006). Estimates of global terrestrial isoprene emissions using MEGAN (Model of Emissions of Gases and Aerosols from Nature). Atmospher. Chem. Phys. 6, 3181-3210. doi: 10.5194/acp-6-3181-2006

Guerzoni, S., Molinaroli, E., and Chester, R. (1997). Saharan dust inputs to the western Mediterranean Sea: depositional patterns, geochemistry and sedimentological implications. Deep Sea Res. II 44, 631-654. doi: 10.1016/S0967-0645(96)00096-3

Hohenegger, C., Brockhaus, P., and Schär, C. (2008). Towards climate simulations at cloud-resolving scales. Meteorologische Zeitschrift 17, 383-394. doi: 10.1127/0941-2948/2008/0303

Holben, B., Eck, T., Slutsker, I., Tanre, D., Buis, J., Setzer, A., et al. (1998). AERONET-A federated instrument network and data archive for aerosol characterization. Remote Sens. Environ. 66, 1-16. doi: 10.1016/S0034-4257(98)00031-5

Hong, S.-Y., Noh, Y., and Dudhia, J. (2006). A new vertical diffusion package with an explicit treatment of entrainment processes. Month. Weather Rev. 134, 2318-2341. doi: 10.1175/MWR3199.1

Huneeus, N., Basart, S., Fiedler, S., Morcrette, J.-J., Benedetti, A., Mulcahy, J., et al. (2016). Forecasting the Northern African dust outbreak towards Europe in April 2011: a model intercomparison. Atmospher. Chem. Phys. 16, 4967-4986. doi: 10.5194/acp-16-4967-2016

Huneeus, N., Schulz, M., Balkanski, Y., Griesfeller, J., Prospero, J., Kinne, S., et al. (2011). Global dust model intercomparison in AeroCom phase I. Atmospher. Chem. Phys. 11, 7781-7816. doi: 10.5194/acp-11-7781-2011

Iacono, M. J., Delamere, J. S., Mlawer, E. J., Shephard, M. W., Clough, S. A., and Collins, W. D. (2008). Radiative forcing by long-lived greenhouse gases: calculations with the AER radiative transfer models. J. Geophys. Res. 113:D13103. doi: 10.1029/2008JD009944

Israelevich, P., Ganor, E., Alpert, P., Kishcha, P., and Stupp, A. (2012). Predominant transport paths of Saharan dust over the Mediterranean Sea to Europe. J. Geophys. Res. 117:D02205. doi: 10.1029/2011JD016482

Jacob, D., Petersen, J., Eggert, B., Alias, A., Christensen, O. B., Bouwer, L. M., et al. (2014). EURO-CORDEX: new high-resolution climate change projections for european impact research. Region. Environ. Change 14, $563-$ 578. doi: 10.1007/s10113-013-0499-2

Janssens-Maenhout, G., Dentener, F., Van Aardenne, J., Monni, S., Pagliari, V., Orlandini, L., et al. (2012). "EDGAR-HTAP: a harmonized gridded air pollution emission dataset based on national inventories," in European Commission Joint Research Centre Institute for Environment and Sustainability. JRC 68434 UR 25229 EUR 25229 (Luxembourg).

Jiménez, P., Lelieveld, J., and Baldasano, J. (2006). Multiscale modeling of air pollutants dynamics in the northwestern Mediterranean basin during a typical summertime episode. J. Geophys. Res. 111:D18306. doi: 10.1029/2005JD006516

Kaskaoutis, D. G., Kosmopoulos, P. G., Nastos, P. T., Kambezidis, H. D., Sharma, M., and Mehdi, W. (2012). Transport pathways of Sahara dust over Athens, Greece as detected by MODIS and TOMS. Geomat. Nat. Hazards Risk 3, 35-54. doi: 10.1080/19475705.2011.574296

Klingmüller, K., Lelieveld, J., Karydis, V. A., and Stenchikov, G. L. (2019). Direct radiative effect of dust-pollution interactions. Atmospher. Chem. Phys. 19, 7397-7408. doi: 10.5194/acp-19-7397-2019

Knippertz, P., and Todd, M. C. (2012). Mineral dust aerosols over the Sahara: meteorological controls on emission and transport and implications for modeling. Rev. Geophys. 50:RG1007. doi: 10.1029/2011RG000362

Kusunoki, S., Yoshimura, J., Yoshimura, H., Noda, A., Oouchi, K., and Mizuta, R. (2006). Change of baiu rain band in global warming projection by an atmospheric general circulation model with a $20-\mathrm{km}$ grid size. J. Meteorol. Soc. Jpn. Ser. II 84, 581-611. doi: 10.2151/jmsj.84.581

Levy, R. C., Mattoo, S., Munchak, L. A., Remer, L. A., Sayer, A. M., Patadia, F., et al. (2013). The collection 6 MODIS aerosol products over land and ocean. Atmospher. Meas. Techniq. 6, 2989-3034. doi: 10.5194/amt-6-29892013

Liu, M., and Westphal, D. L. (2001). A study of the sensitivity of simulated mineral dust production to model resolution. J. Geophys. Res. 106, 18099-18112. doi: 10.1029/2000JD900711

Mass, C. F., Ovens, D., Westrick, K., and Colle, B. A. (2002). Does increasing horizontal resolution produce more skillful forecast? Bull. Am. Meteorol. Soc. 83, 407-430.

Meloni, D., di Sarra, A., Biavati, G., DeLuisi, J., Monteleone, F., Pace, G., et al. (2007). Seasonal behavior of Saharan dust events at the Mediterranean island of Lampedusa in the period 1999-2005. Atmospher. Environ. 41, 3041-3056. doi: 10.1016/j.atmosenv.2006.12.001

Mhawish, A., Banerjee, T., Broday, D. M., Misra, A., and Tripathi, S. N. (2017). Evaluation of MODIS collection 6 aerosol retrieval algorithms over 
Indo-Gangetic Plain: implications of aerosols types and mass loading. Remote Sens. Environ. 201, 297-313. doi: 10.1016/j.rse.2017.09.016

Michaelides, S., Karacostas, T., Sánchez, J. L., Retalis, A., Pytharoulis, I., Homar, V., et al. (2018). Reviews and perspectives of high impact atmospheric processes in the Mediterranean. Atmospher. Res. 208, 4-44. doi: 10.1016/j.atmosres.2017.11.022

Middleton, N. J., and Goudie, A. S. (2001). Saharan Dust: sources and Trajectories. Trans. Inst. Brit. Geogr. 26, 165-181. doi: 10.1111/1475-5661.00013

Millán, M. M., Salvador, R., Mantilla, E., and Kallos, G. (1997). Photooxidant dynamics in the Mediterranean basin in summer: results from European research projects. J. Geophys. Res. Atmospher. 102, 8811-8823. doi: 10.1029/96JD03610

Morrison, H., Thompson, G., and Tatarskii, V. (2009). Impact of cloud microphysics on the development of trailing stratiform precipitation in a simulated squall line: comparison of one- and two-moment schemes. Month. Weather Rev. 137, 991-1007. doi: 10.1175/2008MWR2556.1

Moulin, C., Lambert, C. E., Dayan, U., Masson, V., Ramonet, M., Bousquet, P., et al. (1998). Satellite climatology of African dust transport in the Mediterranean atmosphere. J. Geophys. Res. 103, 13137-13144. doi: 10.1029/98JD00171

Nabat, P., Somot, S., Mallet, M., Sevault, F., Chiacchio, M., and Wild, M. (2015). Direct and semi-direct aerosol radiative effect on the Mediterranean climate variability using a coupled regional climate system model. Clim. Dyn. 44, 1127-1155. doi: 10.1007/s00382-014-2205-6

Nisantzi, A., Mamouri, R. E., Ansmann, A., Schuster, G. L., and Hadjimitsis, D. G. (2015). Middle East versus Saharan dust extinction-to-backscatter ratios. Atmospher. Chem. Phys. 15, 7071-7084. doi: 10.5194/acp-15-7071-2015

Oouchi, K., Yoshimura, J., Yoshimura, H., Mizuta, R., Kusunoki, S., and Noda, A. (2006). Tropical cyclone climatology in a global-warming climate as simulated in a $20 \mathrm{~km}$-mesh global atmospheric model: frequency and wind intensity analyses. J. Meteorol. Soc. Jpn. Ser. II 84, 259-276. doi: 10.2151/jmsj.84.259

Palacios-Peña, L., Baró, R., Baklanov, A., Balzarini, A., Brunner, D., Forkel, R., et al. (2018). An assessment of aerosol optical properties from remote-sensing observations and regional chemistry-climate coupled models over Europe. Atmospher. Chem. Phys. 18, 5021-5043. doi: 10.5194/acp-18-5021-2018

Palacios-Peña, L., Baró, R., Guerrero-Rascado, J. L., Alados-Arboledas, L., Brunner, D., and Jiménez-Guerrero, P. (2017). Evaluating the representation of aerosol optical properties using an online coupled model over the Iberian Peninsula. Atmospher. Chem. Phys. 17, 277-296. doi: 10.5194/acp-17-277-2017

Palacios-Peña, L., Jiménez-Guerrero, P., Baró, R., Balzarini, A., Bianconi, R., Curci, G., et al. (2019). Aerosol optical properties over Europe: an evaluation of the AQMEII phase 3 simulations against satellite observations. Atmospher. Chem. Phys. 19, 2965-2990. doi: 10.5194/acp-19-2965-2019

Pandolfi, M., Cusack, M., Alastuey, A., and Querol, X. (2011). Variability of aerosol optical properties in the Western Mediterranean Basin. Atmospher. Chem. Phys. 11, 8189-8203. doi: 10.5194/acp-11-8189-2011

Papadimas, C. D., Hatzianastassiou, N., Matsoukas, C., Kanakidou, M., Mihalopoulos, N., and Vardavas, I. (2012). The direct effect of aerosols on solar radiation over the broader Mediterranean basin. Atmospher. Chem. Phys. 12, 7165-7185. doi: 10.5194/acp-12-7165-2012

Pérez, C., Haustein, K., Janjic, Z., Jorba, O., Huneeus, N., Baldasano, J. M., et al. (2011). Atmospheric dust modeling from meso to global scales with the online NMMB/BSC-Dust model; Part 1: model description, annual simulations and evaluation. Atmospher. Chem. Phys. 11, 13001-13027. doi: 10.5194/acp-11-13001-2011

Pérez, C., Sicard, M., Jorba, O., Comerón, A., and Baldasano, J. M. (2004). Summertime re-circulations of air pollutants over the north-eastern iberian coast observed from systematic EARLINET lidar measurements in Barcelona. Atmospher. Environ. 38, 3983-4000. doi: 10.1016/j.atmosenv.2004.04.010

Pey, J., Querol, X., Alastuey, A., Forastiere, F., and Stafoggia, M. (2013). African dust outbreaks over the Mediterranean Basin during 2001-2011: $\mathrm{PM}_{10}$ concentrations, phenomenology and trends, and its relation with synoptic and mesoscale meteorology. Atmospher. Chem. Phys. 13, 1395-1410. doi: 10.5194/acp-13-1395-2013

Pieri, A. B., von Hardenberg, J., Parodi, A., and Provenzale, A. (2015). Sensitivity of precipitation statistics to resolution, microphysics, and convective parameterization: a case study with the high-resolution WRF climate model over Europe. J. Hydrometeorol. 16, 1857-1872. doi: 10.1175/JHM-D-14-0221.1
Planton, S., Lionello, P., Artale, V., Aznar, R., Carrillo, A., Colin, J., et al. (2012). " 8 - the climate of the mediterranean region in future climate projections," in The Climate of the Mediterranean Region, ed P. Lionello (Oxford: Elsevier), 449-502.

Prein, A. F., Holland, G. J., Rasmussen, R. M., Done, J., Ikeda, K., Clark, M. P., et al. (2013). Importance of regional climate model grid spacing for the simulation of heavy precipitation in the colorado headwaters. J. Clim. 26, 4848-4857. doi: 10.1175/JCLI-D-12-00727.1

Prospero, J. M. (1996). "Saharan dust transport over the North Atlantic Ocean and mediterranean: an overview," in The Impact of Desert Dust Across the Mediterranean, eds S. Guerzoni and R. Chester (Dordrecht: Springer), 133-151.

Pryor, S. C., Nikulin, G., and Jones, C. (2012). Influence of spatial resolution on regional climate model derived wind climates. J. Geophys. Res. 117:D03117. doi: 10.1029/2011JD016822

Querol, X., Alastuey, A., Pey, J., Cusack, M., Pérez, N., Mihalopoulos, N., et al. (2009). Variability in regional background aerosols within the Mediterranean. Atmospher. Chem. Phys. 9, 4575-4591. doi: 10.5194/acp-9-4575-2009

Querol, X., Tobías, A., Pérez, N., Karanasiou, A., Amato, F., Stafoggia, M., et al. (2019). Monitoring the impact of desert dust outbreaks for air quality for health studies. Environ. Int. 130:104867. doi: 10.1016/j.envint.2019.05.061

Randall, D. A., Wood, R. A., Bony, S., Colman, R., Fichefet, T., Fyfe, J., et al. (2007). "Climate models and their evaluation," in Climate Change 2013: The Physical Science Basis. Contribution of Working Group I to the Fouth Assessment Report of the Intergovernmental Panel on Climate Change, eds S. Solomon, D. Qin, M. Manning, A. Chen, M. Marquis, K. Averyt, M. Tignor, and H. Miller (Cambridge; New York, NY: Cambridge University Press), 589-662.

Rasmussen, R., Liu, C., Ikeda, K., Gochis, D., Yates, D., Chen, F., et al. (2011). High-resolution coupled climate runoff simulations of seasonal snowfall over colorado: a process study of current and warmer climate. J. Clim. 24, 30153048. doi: 10.1175/2010JCLI3985.1

Rauscher, S. A., Coppola, E., Piani, C., and Giorgi, F. (2010). Resolution effects on regional climate model simulations of seasonal precipitation over Europe. Clim. Dyn. 35, 685-711. doi: 10.1007/s00382-009-0607-7

Rauscher, S. A., Seth, A., Qian, J.-H., and Camargo, S. J. (2006). Domain choice in an experimental nested modeling prediction system for South America. Theor. Appl. Climatol. 86, 229-246. doi: 10.1007/s00704-0060206-Z

Rizza, U., Barnaba, F., Miglietta, M. M., Mangia, C., Di Liberto, L., Dionisi, D., et al. (2017). WRF-Chem model simulations of a dust outbreak over the central Mediterranean and comparison with multi-sensor desert dust observations. Atmospher. Chem. Phys. 17, 93-115. doi: 10.5194/acp-17-93-2017

Rodríguez, S., Querol, X., Alastuey, A., Kallos, G., and Kakaliagou, O. (2001). Saharan dust contributions to $\mathrm{PM}_{10}$ and TSP levels in Southern and Eastern Spain. Atmospher. Environ. 35, 2433-2447. doi: 10.1016/S1352-2310(00)00496-9

Ruti, P. M., Somot, S., Giorgi, F., Dubois, C., Flaounas, E., Obermann, A., et al. (2016). Med-CORDEX initiative for mediterranean climate studies. Bull. Amer. Meteorol. Soc. 97, 1187-1208. doi: 10.1175/BAMS-D-14-00176.1

Salvador, P., na Artíñano, B., Molero, F., Viana, M., Pey, J., Alastuey, A., et al. (2013). African dust contribution to ambient aerosol levels across central Spain: characterization of long-range transport episodes of desert dust. Atmospher. Res. 127, 117-129. doi: 10.1016/j.atmosres.2011.12.011

Santos-Alamillos, F. J., Pozo-Vázquez, D., Ruiz-Arias, J. A., Lara-Fanego, V., and Tovar-Pescador, J. (2013). Analysis of WRF model wind estimate sensitivity to physics parameterization choice and terrain representation in Andalusia (Southern Spain). J. Appl. Meteorol. Climatol. 52, 1592-1609. doi: 10.1175/JAMC-D-12-0204.1

Sayer, A. M., Munchak, L. A., Hsu, N. C., Levy, R. C., Bettenhausen, C., and Jeong, M.-J. (2014). MODIS Collection 6 aerosol products: comparison between Aqua's e-Deep Blue, Dark Target, and "merged" data sets, and usage recommendations. J. Geophys. Res. 119, 13965-13989. doi: 10.1002/2014JD022453

Schulz, M., Chin, M., and Kinne, S. (2009). The aerosol model comparison project, aeroCom, phase II: clearing up diversity. IGAC Newslett. 41, 2-11.

Shao, Y., Wyrwoll, K.-H., Chappell, A., Huang, J., Lin, Z., McTainsh, G. H., et al. (2011). Dust cycle: an emerging core theme in Earth system science. Aeolian Res. 2, 181-204. doi: 10.1016/j.aeolia.2011.02.001 
Smirnov, A., Holben, B. N., Slutsker, I., Giles, D. M., McClain, C. R., Eck, T. F., et al. (2009). Maritime aerosol network as a component of aerosol robotic network. J. Geophys. Res. 114:D06204.

Soares, J., Sofiev, M., and Hakkarainen, J. (2015). Uncertainties of wild-land fires emission in AQMEII phase 2 case study. Atmospher. Environ. 115, 361-370. doi: 10.1016/j.atmosenv.2015.01.068

Sofiev, M., Vankevich, R., Lotjonen, M., Prank, M., Petukhov, V., Ermakova, T., et al. (2009). An operational system for the assimilation of the satellite information on wild-land fires for the needs of air quality modelling and forecasting. Atmospher. Chem. Phys. 9, 6833-6847. doi: 10.5194/acp-9-6833-2009

Solmon, F., Mallet, M., Elguindi, N., Giorgi, F., Zakey, A., and Konaré, A. (2008). Dust aerosol impact on regional precipitation over Western Africa, mechanisms and sensitivity to absorption properties. Geophys. Res. Lett. 35:L24705. doi: 10.1029/2008GL035900

Stephenson, D. B., Chauvin, F., and Royer, J.-F. (1998). Simulation of the Asian summer monsoon and its dependence on model horizontal resolution. J. Meteorol. Soc. Jpn. Ser. II 76, 237-265. doi: 10.2151/jmsj1965.76.2_237

Stockwell, W. R., Kirchner, F., Kuhn, M., and Seefeld, S. (2001). A new mechanism for regional atmospheric chemistry modeling. J. Geophys. Res. 102, 2584725879. doi: 10.1029/97JD00849

Tewari, M., Chen, F., Wang, W., Dudhia, J., LeMone, M., Mitchell, K., et al. (2004). "Implementation and verification of the unified NOAH land surface model in the WRF model," in 20th Conference on Weather Analysis and Forecasting/16th Conference on Numerical Weather Prediction, Vol. 1115 (Seattle, WA).
UNEP/MAP-Plan Bleu (2009). State of the Environment and Development in the Mediterranean. Athens: UNEP/MAP-Plan Bleu.

Wesely, M. L. (1989). Parameterization of surface resistances to gaseous dry deposition in regional-scale numerical models. Atmospher. Environ. 23, 12931304. doi: 10.1016/0004-6981(89)90153-4

Whetton, P. H., Katzfey, J. J., Hennessy, K. J., Wu, X., McGregor, J. L., and Nguyen, K. (2001). Developing scenarios of climate change for Southeastern Australia: an example using regional climate model output. Clim. Res. 16, 181-201. doi: $10.3354 / \mathrm{cr} 016181$

Wiedinmyer, C., Akagi, S., Yokelson, R. J., Emmons, L., Al-Saadi, J., Orlando, J., et al. (2011). The fire INventory from NCAR (FINN): a high resolution global model to estimate the emissions from open burning. Geosci. Model Dev. 4:625. doi: 10.5194/gmd-4-625-2011

Conflict of Interest: The authors declare that the research was conducted in the absence of any commercial or financial relationships that could be construed as a potential conflict of interest.

Copyright (c) 2019 Palacios-Peña, Lorente-Plazas, Montávez and Jiménez-Guerrero. This is an open-access article distributed under the terms of the Creative Commons Attribution License (CC BY). The use, distribution or reproduction in other forums is permitted, provided the original author(s) and the copyright owner(s) are credited and that the original publication in this journal is cited, in accordance with accepted academic practice. No use, distribution or reproduction is permitted which does not comply with these terms. 